\title{
Heliophyllite: a discredited mineral species identical to ecdemite
}

\author{
Natale Perchiazzi ${ }^{1}$, Ulf Hålenius ${ }^{2}$, Nicola Demitri ${ }^{3}$, and Pietro Vignola ${ }^{4}$ \\ ${ }^{1}$ Dipartimento di Scienze della Terra, Università di Pisa, Via Santa Maria 53, 56126 Pisa, Italy \\ ${ }^{2}$ Department of Geosciences, Swedish Museum of Natural History, P.O. Box 50 007, \\ 10405 Stockholm, Sweden \\ ${ }^{3}$ Elettra - Sincrotrone Trieste S.C.p.A., S.S. 14 KM 163,5 in Area Science Park - loc. Basovizza, \\ 34149 Trieste, Italy \\ ${ }^{4}$ Istituto di Geologia Ambientale e Geoingegneria, Via Mario Bianco 9, 20131 Milan, Italy
}

Correspondence: Natale Perchiazzi (natale.perchiazzi@unipi.it)

Received: 28 January 2020 - Revised: 5 March 2020 - Accepted: 17 March 2020 - Published: 2 April 2020

\begin{abstract}
The type material for heliophyllite, preserved in the Swedish Museum of Natural History in Stockholm, was re-investigated through a combined EPMA (electron probe X-ray microanalysis), Raman, and X-ray powder diffraction (XRPD) and single-crystal study. EPMA chemical data, together with Raman and singlecrystal structural studies, point to heliophyllite being identical to ecdemite. XRPD synchrotron data highlight the presence of a minor quantity of finely admixed finnemanite in the analyzed material, explaining the presence of some additional diffraction peaks, not indexable with the ecdemite unit cell, reported in the literature.

The discreditation of heliophyllite has been approved by the IMA Commission on New Minerals and Mineral Names (proposal 19-H, 2019).
\end{abstract}

\section{Introduction}

The status of the mineral heliophyllite, $\mathrm{Pb}_{6} \mathrm{As}_{2} \mathrm{O}_{7} \mathrm{Cl}_{4}$, and its relation to ecdemite have been matters of debate since its discovery. In the most recent version (January 2020) of the IMA List of Minerals (at http://cnmnc.main.jp, last access: 29 March 2020), the status of heliophyllite is defined as questionable $(Q)$, suggesting doubtful validity. Ecdemite was discovered at Långban in the Värmland province of central Sweden by Nordenskiöld (1877), and a decade later the closely related new mineral heliophyllite was reported by Flink (1888) from the neighboring Långban-type deposit at a Harstigen, Pajsberg, ore field. Ecdemite was described by Nordenskiöld (1877) as tetragonal and uniaxial, with the ideal chemical formula $\mathrm{Pb}_{7} \mathrm{As}_{2} \mathrm{O}_{8} \mathrm{Cl}_{4}$. Nordenskiöld (1877) moreover reported the occurrence of an admixed minor phase composed of the same chemical elements as ecdemite but with a biaxial optical character. Flink (1888) described heliophyllite as orthorhombic pseudo-tetragonal, with the chemical formula $\mathrm{Pb}_{6} \mathrm{As}_{2} \mathrm{O}_{7} \mathrm{Cl}_{4}$, and possessing an optically biaxial negative character. Hamberg (1889) performed optical and chemical studies on a series of samples of ecdemiteheliophyllite samples from Harstigen. He grouped the investigated samples into "type I", made up of equal proportions of uniaxial ecdemite and biaxial heliophyllite, and "type II", composed of uniaxial ecdemite only. He proposed ecdemite and heliophyllite as polymorphs with the chemical formula $\mathrm{Pb}_{13} \mathrm{As}_{4} \mathrm{O}_{15} \mathrm{Cl}_{8}$. Sillén and Melander (1941) examined ecdemite from Harstigen and Jakobsberg through optical and $\mathrm{X}$-ray single-crystal and powder diffraction studies. Weissenberg photographs performed on a cleavage plate from Harstigen showed an "apparent perfect" $P 4 / \mathrm{mmm}$ tetragonal symmetry, with $a=10.8$ and $c=25.6 \AA$. However, the mineral displayed a distinct optical biaxial character, with only a small fraction of crystals showing an uniaxial character. Xray powder diffraction (XRPD) studies performed on both Harstigen and Jakobsberg ecdemite specimens highlighted the presence of a minor undefined additional phase besides the major pseudo-tetragonal phase. Powder diffraction patterns for ecdemite and heliophyllite (PDF cards 23-343 and 20-0471 respectively) from the Långban and Harstigen mines 
were reported by Welin (1968). The recorded diffraction patterns of the two minerals showed very close resemblance, with the only differences in peak intensities and the presence of an additional diffraction line, with $d_{\text {ret }}=3.05 \AA$, in the ecdemite pattern (Powder Diffraction File database card 23343). The ecdemite pattern was indexed by Welin (1968) on the basis of the unit cell given by Sillén and Melander (1941), with $a=10.8$ and $c=25.62 \AA$, whereas the heliophyllite pattern was indexed on an orthorhombic cell, resulting in the following unit cell parameters: $a=10.823, b=10.783$ and $c=25.58 \AA$. Neither space group indications nor estimated standard deviations for cell parameters were reported. The data for heliophyllite published by Welin (1968) are reported in the Powder Diffraction File database (card 20-471) as questionable because of a poor fit between observed and calculated $d$ values (SS/FOM:F18 $=1(0.0230,797))$.

In a paper devoted to the study of $\mathrm{Pb}$ oxychlorides from Långban-type deposits, Jonsson (2003) reported, for the first time, detailed EPMA chemical data for both ecdemite and heliophyllite together with X-ray powder diffraction and Raman spectra: samples from Långban as well as Harstigen were studied by Jonsson (2003). He demonstrated that, apart from a limited $\mathrm{Sb}^{3+} \leftrightarrow \mathrm{As}^{3+}$ substitution, found both in Långban and Harstigen samples, the composition of four studied samples appeared remarkably uniform, pointing to the chemical formula $\mathrm{Pb}_{6} \mathrm{As}_{2} \mathrm{O}_{7} \mathrm{Cl}_{4}$. In addition, several samples of ecdemite and heliophyllite, including the type I and II specimens of Hamberg (1889), were studied by Jonsson (2003) through Raman micro-spectrometry, resulting in a set of remarkably similar spectra. Although XRPD patterns were not reported in detail in the paper by Jonsson (2003), cell parameters calculated from indexed powder patterns of both ecdemite and heliophyllite were presented. Regarding ecdemite, Jonsson (2003) noticed that poor indexing is obtained for the pattern using the cell suggested by Welin (1968), proposing instead a tetragonal cell with $a=5.42$ and $c=12.80 \AA$. The heliophyllite pattern was indexed by Jonsson (2003) on the basis of an orthorhombic cell close to that given by Welin (1968), namely $a=10.85$, $b=10.79$ and $c=25.58 \AA$. Neither space group indications nor estimated standard deviations for cell parameters were given for the two phases. A crystal-chemical study of the holotype ecdemite was recently reported by Perchiazzi et al. (2019). The crystal structure of ecdemite was solved and refined through synchrotron single-crystal data, showing that ecdemite is actually monoclinic pseudo-tetragonal, $P 2{ }_{1}$, with $a=10.8276(38), b=10.8265(21), c=6.9705(14) \AA$ and $\beta=113.261(24)^{\circ}$. Ecdemite is a member of the layered lead oxyhalide group, generally referred to as Aurivillius phases (Aurivillius, 1982, 1983), and its crystal structure is made up of a $1: 1$ sequence of regularly alternating defective litharge-like layers (Boher et al., 1985), which also host As cations, and $\mathrm{Cl}$ layers. For a comprehensive description of this mineral group, we refer to Siidra et al. $(2008,2011$,
Table 1. EPMA chemical data (wt \%) for heliophyllite from holotype specimen NRM18880482 (1). F, P, Ca, V, Mn and Fe were below their respective detection limits in all spot analyses. Chemical data for ecdemite (2) in Perchiazzi et al. (2019) are given for comparison.

\begin{tabular}{lrrrrr}
\hline & \multicolumn{2}{c}{$(1)$} & & \multicolumn{2}{c}{$(2)$} \\
\cline { 2 - 3 } \cline { 5 - 6 } & $n=10$ & $1 \sigma$ & & $n=10$ & $1 \sigma$ \\
$\mathrm{As}_{2} \mathrm{O}_{3}$ & 11.62 & 0.16 & & 11.46 & 0.30 \\
$\mathrm{Sb}_{2} \mathrm{O}_{3}$ & 0.52 & 0.13 & & 0.71 & 0.13 \\
$\mathrm{PbO}$ & 80.97 & 0.53 & & 81.42 & 0.74 \\
$\mathrm{Cl}$ & 8.66 & 0.09 & & 8.66 & 0.06 \\
$\mathrm{Sum}$ & 101.77 & & & 102.25 & \\
$-\mathrm{O}=\mathrm{Cl}$ & -1.95 & & & -1.95 & \\
$\mathrm{Sum}$ & 99.81 & & & 100.30 & \\
\hline
\end{tabular}

2013a, b, c), Krivovichev et al. (2009, 2013) and Chukanov et al. (2019).

In the following we report results of a new multitechnique investigation of a heliophyllite holotype material, submitted to the IMA Commission on New Minerals and Mineral Names, which proved the discreditation of heliophyllite (proposal 19-H, 2019).

\section{Samples and experimental}

Heliophyllite crystal fragments were selected from the holotype material studied by Flink (1888), deposited in the collections of the Swedish Museum of Natural History in Stockholm under catalogue numbers NRM18880481 and NRM18880482. Heliophyllite crystals are translucent, with a yellow-greenish color, adamantine luster and perfect cleavage. Jonsson (2003) reports, as associated phases, hydrocerussite, ecdemite, rhodonite, baryte, calcite and finnemanite. We were able to identify, through X-ray diffraction (XRD) studies, baryte, finnemanite, hydrocerussite and inesite as admixed accessories within heliophyllite fragments.

Unpolarized micro-Raman spectra were collected on cleavage plates of heliophyllite, previously analyzed by EMPA (electron probe X-ray microanalysis), in nearly backscattered geometry with a Jobin Yvon Horiba XploRA PLUS apparatus, equipped with a motorized $x-y$ stage and an Olympus BX41 microscope with a $10 \times$ objective. The Raman spectra were excited using a $532 \mathrm{~nm}$ line of a solidstate laser attenuated to $25 \%$ in order to minimize the sample damage. The minimum lateral and depth resolution was set to a few micrometers. The system was calibrated using the $520.5 \mathrm{~cm}^{-1}$ Raman band of silicon before each experimental session. Spectra were collected through multiple acquisitions with single counting times of $30 \mathrm{~s}$. Backscattered radiation was analyzed with a $1200 \mathrm{~mm}^{-1}$ grating monochromator.

Quantitative chemical data were collected on heliophyllite NRM18880482 through a JEOL JXA-8200 electron micro- 
Table 2. Experimental details for heliophyllite single-crystal structural study.

\begin{tabular}{ll}
\hline Crystal data & Data collection and refinement \\
\hline Crystal-chemical formula & Maximum $2 \theta ; 65.51^{\circ}$ \\
$\mathrm{Pb}_{6} \mathrm{Cl}_{4} \mathrm{As}_{2}^{3+} \mathrm{O}_{7}$ & MoK $\alpha, \lambda=0.71073 \AA$ \\
Crystal size: $0.05 \times 0.04 \times 0.01 \mathrm{~mm}$ & Collected reflections: 6647 \\
Space group: $P 2_{1}$ & Unique reflections: $4635, R_{\text {int }}=0.044$ \\
$a=10.838(2) \AA$ & Observed reflections: $3435>4 \sigma(F \mathrm{o})$ \\
$b=10.839(2) \AA$ & $h, k, l-14 \leq h \leq 15,-16 \leq k \leq 16,-10 \leq l \leq 10$ \\
$c=6.981(1) \AA$ & $R\left[F^{2}>4 \sigma\left(F^{2}\right)\right], w R\left(F^{2}\right), \mathrm{S} 0.047,0.089,0.979$ \\
$\beta=113.28(1)^{\circ}$ & Flack $x=0.02(2),\left|E^{2}-1\right|=0.759$ \\
$V=753.4(2) \AA^{3}, Z=2$ & No. of parameters, restraints: 185,7 \\
$\rho_{\text {calc }}=7.79 \mathrm{~g} \mathrm{~cm}^{-3}, \rho_{\text {meas }}=6.89-7.14 \mathrm{~g} \mathrm{~cm}^{-3}$ & $\Delta \rho_{\text {max }}, \Delta \rho_{\text {min }}\left(\mathrm{e}-\AA^{3}\right)+3.47,-2.91$ \\
$\mu=7.28 \mathrm{~cm}^{-1}$ & \\
\hline
\end{tabular}

probe at the Department of Earth Sciences "Ardito Desio", University of Milan (ESD-MI). The analytical conditions were as follows: wavelength-dispersive spectroscopy (WDS) mode, accelerating voltage of $15 \mathrm{kV}$, beam current of $5 \mathrm{nA}$, beam size of $7 \mu \mathrm{m}$, and counting times of $30 \mathrm{~s}$ on the peaks and $10 \mathrm{~s}$ in the right and left background. The following standards were used: graftonite KF-16 (Fransolet, 1975) for P, Fe, $\mathrm{Mn}$ and $\mathrm{Ca}$; realgar for As; olivine for $\mathrm{Mg}$; hornblende for $\mathrm{F}$; scapolite for Cl; pure metals (99.99 wt \%) for Sb and V; and synthetic $\mathrm{PbO}$ for $\mathrm{Pb}$. The raw data were corrected for matrix effects using the $\varphi \rho Z$ method from the JEOL series of programs. Following literature chemical data and structural study indications, all the $\mathrm{Sb}$ and As (Table 1) was reported as trivalent.

A set of 18 progressively smaller cleavage laminas were investigated by the single-crystal intensity data collection, performed at the Earth Science Department of the University of Pisa, employing a Bruker SMART BREEZE diffractometer equipped with an air-cooled charge-coupled device (CCD) detector. Heliophyllite diffraction patterns showed the same features already reported for ecdemite by Perchiazzi et al. (2019), namely the presence of complex intergrowths, multiple twinning and a variable degree of structural disorder, highlighted by reflections streaked along $c *$. Unsuccessful trials were made to solve the heliophyllite structure in the orthorhombic system: the assumption of a pseudo-tetragonal unit cell with $a=b \sim 10.8$ and $c \sim 25.65 \AA$ A, namely close to that proposed by Welin (1968), resulted in quite large $R_{\text {int }}$ values of $\sim 27 \%$. Distinctly lower $R_{\text {int }}$ values of $\sim 4 \%-5 \%$ resulted instead, assuming a monoclinic symmetry and an ecdemite-like unit cell.

Single-crystal intensity data were collected on a $0.05 \mathrm{~mm} \times 0.04 \mathrm{~mm} \times 0.01 \mathrm{~mm}$ cleavage lamina, selected from holotype sample NRM18880482. Operating conditions were $50 \mathrm{kV}$ and $30 \mathrm{~mA}$, graphite monochromatized MoK $\alpha$ radiation, and a detector-to-crystal working distance of $50 \mathrm{~mm}$. A total of 1488 frames were collected using $\varphi$ - and $\omega$-scan modes, with an exposure time of $20 \mathrm{~s}$ per frame.
Intensity data were integrated and corrected for Lorentz polarization, background effects and absorption using the APEX 3 software package (Bruker AXS Inc., 2016). The heliophyllite structure was refined starting from the structural model of ecdemite, with SHELXL-2014 (Sheldrick, 2015) within the WinGX program suite (Farrugia, 2012). Scattering curves for neutral atoms were taken from the International Tables for Crystallography (Wilson, 1992). Heliophyllite is monoclinic, $P 2_{1}$, with $a=10.838(2)$, $b=10.839(2), c=6.981(1) \AA$ and $\beta=113.28(1)^{\circ}$. Details of data collection and crystal structure refinement are reported in Table 2.

Heliophyllite fragments from sample NMR18880482, carefully selected under a binocular microscope at $80 \times$ magnification, were gently hand milled under acetone, loading the resulting powder into a $0.5 \mathrm{~mm}$ borosilicate capillary. Synchrotron X-ray powder diffraction data collection $(\lambda=0.59041 \AA)$ was performed at the XRD1 (Lausi et al., 2015) beamline of the Elettra synchrotron facility. A Rietveld refinement was performed through the TOPASAcademic program (Coelho, 2018) on the heliophyllite pattern, assuming the single-crystal structure model. Cell parameters only were refined, leaving both the atomic positional and displacement parameters for the heliophyllite model unchanged. The background was modeled with a $1 / x$ function, effective for describing background intensity at low angles due to air scattering, and with a nine-term Chebyshev function. Absorption was corrected according to the approach by Sabine et al. (1998). The effects of asymmetry and zero error were accounted for and found to be negligible. The instrumental contribution to the peak shape was modeled through a pseudo-Voigt function by fitting the data of a sample of SRM 660a $\left(\mathrm{LaB}_{6}\right)$ collected under the same experimental setup. Peak shape broadening was modeled while taking into account Gaussian crystallite size and microstrain contributions. During the refinement, some misfit between the observed and calculated patterns suggested the presence of accessory phases and, including the pres- 


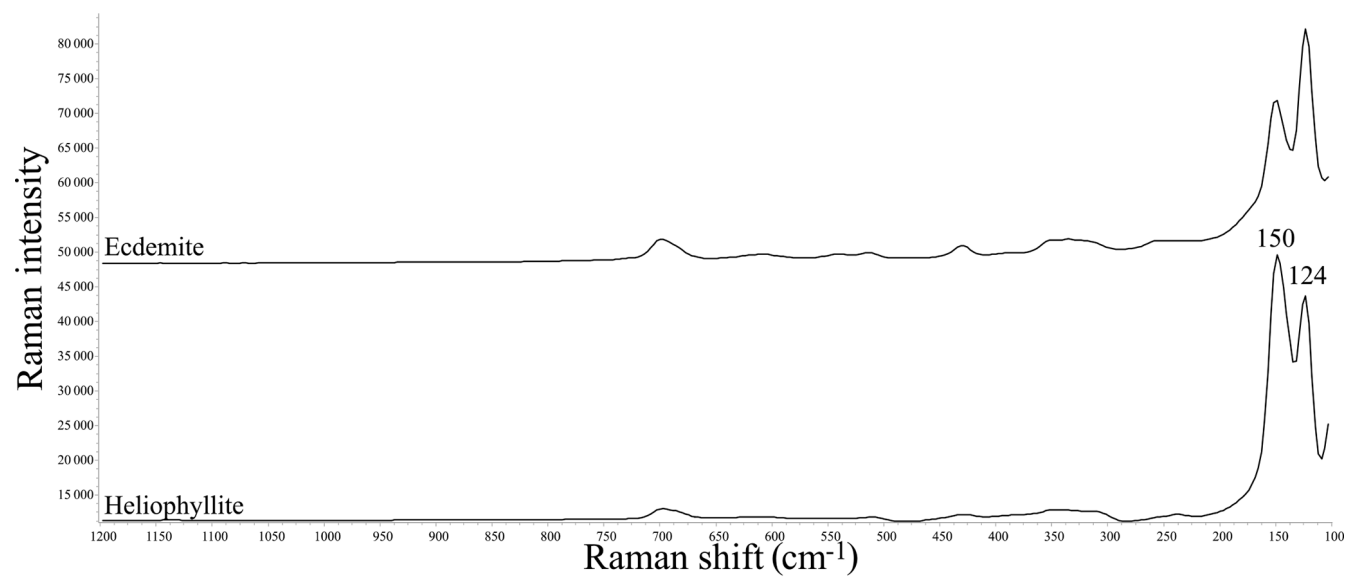

(a)

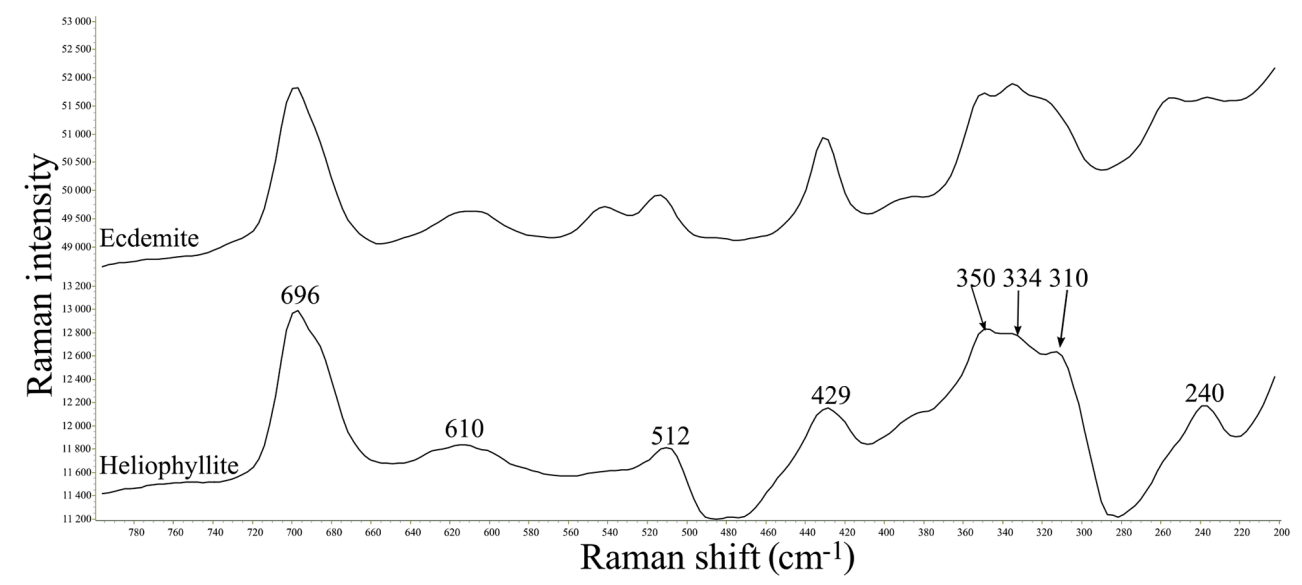

(b)

Figure 1. (a) Raman spectrum of heliophyllite holotype specimen NRM18880482 (lower spectrum) compared with the Raman spectrum of ecdemite specimen NRM19331765 from Harstigen (upper spectrum from Perchiazzi et al., 2019) in the range $100-1200 \mathrm{~cm}^{-1}$. (b) Heliophyllite: close-up of the spectral region between 200 and $800 \mathrm{~cm}^{-1}$.

ence of finnemanite $(3.7 \%)$ and hydrocerussite $(6.4 \%)$, significantly improved the Rietveld fit. Refined cell parameters for heliophyllite were $a=10.843(1), b=10.843(1), c=$ $6.9648(7) \AA$ and $\beta=113.102(2)^{\circ}$, with Rietveld refinement agreement factors of $R_{\mathrm{wp}}=4.657, R_{\mathrm{exp}}=1.407, R_{\mathrm{p}}=3.503$ and $\mathrm{GoF}=3.311$. Table 3 reports the $\mathrm{X}$-ray powder pattern for heliophyllite compared with Welin (1968) dataset.

\section{Discussion}

Chemical, optical and structural data for ecdemite and heliophyllite presented in literature, especially the older datasets, give contrasting indications on the true nature of these minerals. Regarding ecdemite, the recent study of Perchiazzi et al. (2019) established its true monoclinic symmetry. Previous to this study, only one X-ray single-crystal study (Weissenberg photographs) of ecdemite had been published (Sillén and Melander, 1941). It is worth noting that Sillén and Me- lander (1941) report a distinct optical biaxial character for ecdemite, correctly remarking that this is incompatible with a tetragonal crystal symmetry. A biaxial character is in full agreement with the true monoclinic symmetry of ecdemite. The correct chemical formula for ecdemite was initially suggested by Palache et al. (1951) and subsequently confirmed through modern chemical electron microprobe analyses by Jonsson (2003) and Perchiazzi et al. (2019). Regarding heliophyllite, the original study of Flink (1888) suggests the mineral formula $\mathrm{Pb}_{6} \mathrm{Cl}_{4} \mathrm{As}_{2} \mathrm{O}_{7}$, an optical biaxial character and an orthorhombic pseudo-tetragonal symmetry inferred through goniometric measurements. The chemical and optical data given in Flink (1888) are in agreement with the present study.

Our chemical data for the heliophyllite holotype specimen NMR18880482 are reported in Table 1 together with chemical data for ecdemite (Perchiazzi et al., 2019) for comparison. The empirical formula for heliophyllite calcu- 
Table 3. Synchrotron X-ray powder pattern of NRM18880482 heliophyllite (1) compared with (2) X-ray diffraction data from Welin (1968).

\begin{tabular}{|c|c|c|c|c|c|}
\hline \multicolumn{3}{|c|}{ (1) } & \multicolumn{3}{|c|}{ (2) } \\
\hline$d_{\mathrm{obs}}$ & $(h k l)$ & $I_{\text {rel }}$ & $d_{\mathrm{obs}}$ & $(h k l)$ & $I_{\text {rel }}$ \\
\hline 7.337 & 110 & 1 & & & \\
\hline 6.401 & 001 & 9 & 6.38 & 004 & 6 \\
\hline 5.720 & $1-1-1$ & 1 & & & \\
\hline 5.521 & 011 & 2 & & & \\
\hline 4.761 & 120 & 1 & & & \\
\hline 4.530 & $210 ; 2-1-1$ & 2 & & & \\
\hline 4.236 & $111 ; 1-2-1$ & 1 & & & \\
\hline 3.673 & $2-2-1 ; 220$ & 52 & 3.66 & 222 & 35 \\
\hline 3.605 & 30-1 & 2 & & & \\
\hline 3.201 & 002 & 18 & 3.19 & 126 & 20 \\
\hline 3.147 & 031 & 3 & & & \\
\hline 2.923 & $1-2-2$ & 4 & & & \\
\hline 2.852 & $2-2-2 ; 221$ & 100 & 2.84 & 135 & 100 \\
\hline 2.710 & $-401 ; 040$ & 47 & 2.70 & 040 & 40 \\
\hline 2.626 & $4-1-1 ; 140$ & 7 & 2.62 & 140 & 4 \\
\hline 2.494 & $1-3-2 ;-402$ & 1 & & & \\
\hline 2.454 & 231 & 2 & & & \\
\hline 2.232 & $1-1-3$ & 1 & & & \\
\hline 2.167 & $4-3-1 ; 3-4-1$ & 3 & 2.16 & 340 & 4 \\
\hline 2.132 & $003 ; 2-2-3$ & 6 & 2.13 & 342 & 10 \\
\hline 2.095 & 013 & 1 & & & \\
\hline 2.068 & $042 ; 401$ & 26 & 2.06 & 503 & 25 \\
\hline 2.000 & $5-2-1 ; 3-4-2$ & 3 & & & \\
\hline 1.935 & 142 & 1 & & & \\
\hline 1.916 & $4-4-1$ & 21 & 1.911 & 254 & 20 \\
\hline 1.838 & 033 & 2 & & & \\
\hline 1.820 & $1-5-2 ; 251$ & 1 & & & \\
\hline 1.767 & $5-2-3$ & 1 & & & \\
\hline 1.700 & $6-2-2 ; 260 ; 2-6-1$ & 15 & 1.695 & 622 & 10 \\
\hline 1.677 & 043 & 11 & 1.674 & 2.4 .11 & 12 \\
\hline 1.649 & $223 ; 4-4-3$ & 14 & 1.647 & 264 & 25 \\
\hline 1.591 & $2-6-2 ; 261 ; 6-2-3$ & 27 & 1.587 & 626 & 25 \\
\hline 1.520 & $432 ; 4-3-4$ & 1 & & & \\
\hline 1.507 & $071 ; 630$ & 2 & & & \\
\hline 1.425 & 442 & 6 & 1.425 & 6.0 .11 & 4 \\
\hline 1.379 & 044 & 3 & 1.376 & 652 & 4 \\
\hline 1.354 & $080 ;-802$ & 8 & 1.353 & 800 & 4 \\
\hline 1.344 & $8-1-2 ; 180$ & 4 & 1.341 & 740 & 2 \\
\hline \multirow[t]{2}{*}{1.316} & $4-7-2 ; 470$ & 2 & & & \\
\hline & & & 1.28 & & 2 \\
\hline 1.271 & & 3 & 1.27 & & 2 \\
\hline 1.250 & & 8 & 1.249 & & 10 \\
\hline 1.224 & & 6 & 1.223 & & 6 \\
\hline 1.212 & & 8 & 1.21 & & 6 \\
\hline 1.171 & & 1 & 1.16 & & 2 \\
\hline 1.143 & & 3 & 1.145 & & 2 \\
\hline 1.133 & & 7 & 1.132 & & 2 \\
\hline 1.115 & & 2 & 1.116 & & 2 \\
\hline 1.058 & & 2 & & & \\
\hline 1.031 & & 6 & 1.032 & & 2 \\
\hline 1.008 & & 1 & & & \\
\hline
\end{tabular}

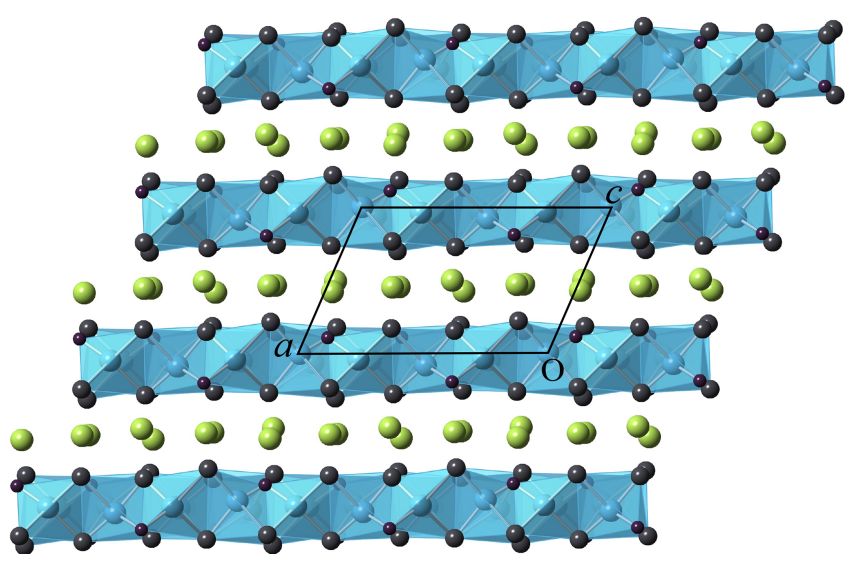

Figure 2. Crystal structure of heliophyllite as seen along [010]. Layers formed by edge-sharing oxocentered $\mathrm{OPb}_{4}$ (cyan) regularly alternate with layers hosting $\mathrm{Cl}$ atoms (yellow).

Table 4. Fractional atomic coordinates and equivalent isotropic displacement parameters $\left(\AA^{2}\right)$ for heliophyllite. According to EPMA chemical composition, a common occupancy for As1 and As2 sites was fixed to As0.97, together with a common occupancy for split $\mathrm{Sb} 1$ and $\mathrm{Sb} 2$ sites of $\mathrm{Sb} 0.03$.

\begin{tabular}{lrrrr}
\hline Atom & $x$ & $y$ & $z$ & Ueq \\
\hline $\mathrm{Pb} 1$ & $0.4238(1)$ & $0.5918(1)$ & $1.2332(2)$ & $0.0155(5)$ \\
$\mathrm{Pb} 2$ & $0.3041(1)$ & $0.8333(1)$ & $0.7880(2)$ & $0.0158(5)$ \\
$\mathrm{Pb} 3$ & $0.1957(1)$ & $0.3499(1)$ & $0.2601(2)$ & $0.0161(4)$ \\
$\mathrm{Pb} 4$ & $1.0808(2)$ & $0.1133(1)$ & $1.7786(2)$ & $0.0183(5)$ \\
$\mathrm{Pb} 5$ & $0.1574(1)$ & $0.8633(1)$ & $1.1927(2)$ & $0.0168(4)$ \\
$\mathrm{Pb} 6$ & $0.5621(1)$ & $0.5832(1)$ & $0.8044(2)$ & $0.0167(5)$ \\
$\mathrm{As} 1$ & $0.3604(3)$ & $0.3252(3)$ & $0.8474(5)$ & $0.011(1)$ \\
$\mathrm{Sb} 1$ & $0.669(8)$ & $-0.139(9)$ & $0.20(1)$ & $0.011(1)$ \\
$\mathrm{As} 2$ & $0.9377(4)$ & $0.1160(4)$ & $1.1504(6)$ & $0.009(1)$ \\
$\mathrm{Sb} 2$ & $0.95(1)$ & $-0.91(9)$ & $0.20(1)$ & $0.009(1)$ \\
$\mathrm{Cl1}$ & $0.9973(8)$ & $0.3615(9)$ & $1.464(1)$ & $0.023(3)$ \\
$\mathrm{Cl} 2$ & $0.2384(8)$ & $0.6058(9)$ & $0.508(1)$ & $0.024(3)$ \\
$\mathrm{Cl} 3$ & $0.5325(7)$ & $1.3339(8)$ & $0.537(1)$ & $0.021(3)$ \\
$\mathrm{C} 14$ & $0.2646(8)$ & $0.0907(9)$ & $0.506(1)$ & $0.024(3)$ \\
$\mathrm{O} 1$ & $0.463(2)$ & $0.451(1)$ & $0.997(3)$ & $0.018(6)$ \\
$\mathrm{O} 2$ & $0.224(2)$ & $0.687(2)$ & $0.998(3)$ & $0.020(8)$ \\
$\mathrm{O} 3$ & $0.274(2)$ & $0.268(2)$ & $1.003(3)$ & $0.022(8)$ \\
$\mathrm{O} 4$ & $0.495(2)$ & $0.215(2)$ & $0.961(3)$ & $0.017(7)$ \\
$\mathrm{O} 5$ & $0.245(2)$ & $0.979(2)$ & $0.994(3)$ & $0.019(8)$ \\
$\mathrm{O} 6$ & $1.022(2)$ & $0.222(2)$ & $1.042(3)$ & $0.015(7)$ \\
$\mathrm{O} 7$ & $0.047(2)$ & $0.496(2)$ & $0.020(3)$ & $0.023(8)$ \\
\hline & & & &
\end{tabular}

lated on the basis of $\mathrm{O}+\mathrm{Cl}=11$ a.p.f.u. (atoms per formula units) is $\mathrm{Pb}_{5.99} \mathrm{As}_{1.94}^{3+} \mathrm{Sb}_{0.06}^{3+} \mathrm{Cl}_{4.03} \mathrm{O}_{6.97}$. The ideal formula is $\mathrm{Pb}_{6} \mathrm{As}_{2} \mathrm{O}_{7} \mathrm{Cl}_{4}$. Heliophyllite appears fairly homogeneous, with a limited substitution of $\mathrm{As}^{3+}$ with $\mathrm{Sb}^{3+}$, as already noted by Jonsson (2003) for ecdemite and heliophyllite and by Perchiazzi et al. (2019) for ecdemite. EPMA data presented in this study confirm the formula $\mathrm{Pb}_{6} \mathrm{As}_{2} \mathrm{O}_{7} \mathrm{Cl}_{4}$ originally proposed by Flink (1888) for heliophyllite. The X- 
Table 5. (a) Selected bond distances $(\AA)$ for heliophyllite. Bond lengths $<3.5 \AA$ were taken into account for Pb coordination. (b) Selected bond distances $(\AA)$ for ecdemite (from Perchiazzi et al., 2019). Bond lengths $<3.5 \AA$ were taken into account for Pb coordination.

\begin{tabular}{|c|c|c|c|c|c|c|c|}
\hline \multicolumn{8}{|l|}{ (a) } \\
\hline \multicolumn{2}{|c|}{$\mathrm{Pb} 1$} & \multicolumn{2}{|c|}{$\mathrm{Pb} 2$} & \multicolumn{2}{|c|}{$\mathrm{Pb} 3$} & \multicolumn{2}{|c|}{ As1 } \\
\hline$-\mathrm{O} 4$ & $2.31(2)$ & -05 & $2.39(2)$ & -06 & $2.35(2)$ & $-\mathrm{O} 3$ & $1.80(2)$ \\
\hline$-\mathrm{O} 2$ & $2.37(2)$ & $-\mathrm{O} 4$ & $2.54(2)$ & $-\mathrm{O} 7$ & $2.40(2)$ & $-\mathrm{O} 1$ & $1.80(2)$ \\
\hline$-\mathrm{O} 1$ & $2.40(2)$ & $-\mathrm{O} 2$ & $2.54(2)$ & $-\mathrm{O} 3$ & $2.43(2)$ & $-\mathrm{O} 4$ & $1.81(2)$ \\
\hline$-\mathrm{Cl} 3$ & $3.014(8)$ & $-\mathrm{O} 1$ & $2.69(2)$ & $-\mathrm{Cl1}$ & $3.01(1)$ & $\mathrm{Sb} 1$ & \\
\hline$-\mathrm{Cl} 4$ & $3.141(9)$ & $-\mathrm{Cl1}$ & $3.052(7)$ & $-\mathrm{Cl} 2$ & $3.206(9)$ & $-\mathrm{O} 1$ & $1.84(8)$ \\
\hline$-\mathrm{Cl} 2$ & $3.29(1)$ & $-\mathrm{Cl} 2$ & $3.049(9)$ & $-\mathrm{Cl} 4$ & $3.22(1)$ & $-\mathrm{O} 3$ & $2.1(1)$ \\
\hline \multirow{2}{*}{$-\mathrm{Cl} 3$} & $3.423(8)$ & $-\mathrm{Cl} 4$ & $3.34(1)$ & $-\mathrm{Cl} 3$ & $3.393(7)$ & $-\mathrm{O} 4$ & $2.32(8)$ \\
\hline & & $-\mathrm{Cl} 3$ & $3.38(1)$ & & & & \\
\hline$<\mathrm{Pb} 1-\mathrm{O}>$ & 2.36 & $<\mathrm{Pb} 2-\mathrm{O}>$ & 2.54 & $<\mathrm{Pb} 3-\mathrm{O}>$ & 2.39 & $<\mathrm{As} 1-\mathrm{O}>$ & 1.80 \\
\hline$<\mathrm{Pb} 1-\mathrm{Cl}>$ & 3.22 & $<\mathrm{Pb} 2-\mathrm{Cl}>$ & 3.21 & $<\mathrm{Pb} 3-\mathrm{Cl}>$ & 3.21 & $<\mathrm{Sb} 1-\mathrm{O}>$ & 2.09 \\
\hline \multicolumn{2}{|c|}{$\mathrm{Pb} 4$} & \multicolumn{2}{|c|}{$\mathrm{Pb} 5$} & \multicolumn{2}{|c|}{$\mathrm{Pb} 6$} & \multicolumn{2}{|c|}{ As2 } \\
\hline$-\mathrm{O} 5$ & $2.33(2)$ & $-\mathrm{O} 5$ & $2.33(2)$ & $-\mathrm{O} 5$ & $2.30(1)$ & $-\mathrm{O} 2$ & $1.81(2)$ \\
\hline-06 & $2.47(2)$ & -06 & $2.52(2)$ & $-\mathrm{O} 4$ & $2.43(2)$ & -06 & $1.81(2)$ \\
\hline$-\mathrm{O} 7$ & $2.66(2)$ & $-\mathrm{O} 7$ & $2.56(2)$ & $-\mathrm{O} 1$ & $2.48(2)$ & -07 & $1.81(2)$ \\
\hline$-\mathrm{O} 3$ & $2.66(2)$ & $-\mathrm{O} 2$ & $2.61(2)$ & $-\mathrm{O} 3$ & $2.67(2)$ & $\mathrm{Sb} 2$ & \\
\hline$-\mathrm{Cl1}$ & $3.134(4)$ & $-\mathrm{Cl} 3$ & $3.154(7)$ & $-\mathrm{Cl} 3$ & $3.228(9)$ & -07 & $1.8(1)$ \\
\hline$-\mathrm{Cl} 2$ & $3.243(8)$ & $-\mathrm{Cl} 4$ & $3.194(9)$ & $-\mathrm{Cl} 2$ & $3.303(8)$ & $-\mathrm{O} 2$ & $2.12(9)$ \\
\hline$-\mathrm{Cl} 4$ & $3.26(1)$ & $-\mathrm{Cl1}$ & $3.425(4)$ & $-\mathrm{Cl} 4$ & $3.38(1)$ & -06 & $2.2(1)$ \\
\hline$-\mathrm{Cl1}$ & $3.365(9)$ & $-\mathrm{Cl} 2$ & $3.45(1)$ & $-\mathrm{Cl3}$ & $3.490(9)$ & & \\
\hline$<\mathrm{Pb} 4-\mathrm{O}>$ & 2.53 & $<\mathrm{Pb} 5-\mathrm{O}>$ & 2.51 & $<\mathrm{Pb} 6-\mathrm{O}>$ & 2.47 & $<\mathrm{As} 2-\mathrm{O}>$ & 1.81 \\
\hline$<\mathrm{Pb} 4-\mathrm{Cl}>$ & 3.25 & $<\mathrm{Pb} 5-\mathrm{Cl}>$ & 3.30 & $<\mathrm{Pb} 6-\mathrm{Cl}>$ & 3.35 & $<\mathrm{Sb} 2-\mathrm{O}>$ & 2.04 \\
\hline \multicolumn{8}{|l|}{ (b) } \\
\hline \multicolumn{2}{|c|}{$\mathrm{Pb} 1$} & \multicolumn{2}{|c|}{$\mathrm{Pb} 2$} & \multicolumn{2}{|c|}{$\mathrm{Pb} 3$} & \multicolumn{2}{|c|}{ As1 } \\
\hline$-\mathrm{O} 4$ & $2.27(1)$ & $-\mathrm{O} 5$ & $2.38(1)$ & -06 & $2.303(9)$ & $-\mathrm{O} 3$ & $1.77(1)$ \\
\hline$-\mathrm{O} 2$ & $2.37(1)$ & $-\mathrm{O} 4$ & $2.529(9)$ & $-\mathrm{O} 7$ & $2.40(1)$ & $-\mathrm{O} 1$ & $1.80(1)$ \\
\hline$-\mathrm{O} 1$ & $2.39(1)$ & $-\mathrm{O} 2$ & $2.53(1)$ & $-\mathrm{O} 3$ & $2.44(1)$ & $-\mathrm{O} 4$ & $1.82(1)$ \\
\hline$-\mathrm{Cl} 3$ & $3.005(4)$ & $-\mathrm{O} 1$ & $2.69(1)$ & $-\mathrm{Cl1}$ & $3.005(5)$ & Sb1 & \\
\hline$-\mathrm{Cl} 4$ & $3.138(4)$ & $-\mathrm{Cl1}$ & $3.047(3)$ & $-\mathrm{Cl} 2$ & $3.198(4)$ & $-\mathrm{O} 1$ & $1.88(1)$ \\
\hline$-\mathrm{Cl} 2$ & $3.282(6)$ & $-\mathrm{Cl} 2$ & $3.049(4)$ & $-\mathrm{Cl} 4$ & $3.218(4)$ & $-\mathrm{O} 3$ & $2.05(2)$ \\
\hline \multirow[t]{2}{*}{$-\mathrm{Cl} 3$} & $3.427(4)$ & $-\mathrm{Cl} 4$ & $3.342(4)$ & $-\mathrm{Cl} 3$ & $3.382(3)$ & $-\mathrm{O} 4$ & $2.32(1)$ \\
\hline & & $-\mathrm{Cl} 3$ & $3.404(4)$ & & & & \\
\hline$<\mathrm{Pb} 1-\mathrm{O}>$ & 2.34 & $<\mathrm{Pb} 2-\mathrm{O}>$ & 2.53 & $<\mathrm{Pb} 3-\mathrm{O}>$ & 2.38 & $<$ As1-O $>$ & 1.80 \\
\hline$<\mathrm{Pb} 1-\mathrm{Cl}>$ & 3.21 & $<\mathrm{Pb} 2-\mathrm{Cl}>$ & 3.21 & $<\mathrm{Pb} 3-\mathrm{Cl}>$ & 3.20 & $<\mathrm{Sb} 1-\mathrm{O}>$ & 2.08 \\
\hline \multicolumn{2}{|c|}{$\mathrm{Pb} 4$} & \multicolumn{2}{|c|}{$\mathrm{Pb} 5$} & \multicolumn{2}{|c|}{$\mathrm{Pb} 6$} & \multicolumn{2}{|c|}{ As2 } \\
\hline$-\mathrm{O} 5$ & $2.332(9)$ & $-\mathrm{O} 5$ & $2.30(1)$ & $-\mathrm{O} 5$ & $2.323(9)$ & $-\mathrm{O} 7$ & $1.80(1)$ \\
\hline-06 & $2.50(1)$ & -06 & $2.52(1)$ & $-\mathrm{O} 4$ & $2.45(1)$ & $-\mathrm{O} 2$ & $1.810(9)$ \\
\hline$-\mathrm{O} 7$ & $2.67(1)$ & $-\mathrm{O} 7$ & $2.57(1)$ & $-\mathrm{O} 1$ & $2.49(1)$ & -06 & $1.81(1)$ \\
\hline$-\mathrm{O} 3$ & $2.69(1)$ & $-\mathrm{O} 2$ & $2.60(1)$ & $-\mathrm{O} 3$ & $2.65(1)$ & & \\
\hline$-\mathrm{Cl1}$ & $3.134(4)$ & $-\mathrm{Cl} 3$ & $3.155(3)$ & $-\mathrm{Cl} 3$ & $3.211(4)$ & $\mathrm{Sb} 2$ & \\
\hline$-\mathrm{Cl} 2$ & $3.244(4)$ & $-\mathrm{Cl} 4$ & $3.185(4)$ & $-\mathrm{Cl} 2$ & $3.294(4)$ & -07 & $1.93(2)$ \\
\hline$-\mathrm{Cl} 4$ & $3.259(5)$ & $-\mathrm{Cl1}$ & $3.425(4)$ & $-\mathrm{Cl} 4$ & $3.376(5)$ & $-\mathrm{O} 2$ & $2.03(1)$ \\
\hline$-\mathrm{Cl1}$ & $3.369(4)$ & $-\mathrm{Cl} 2$ & $3.445(4)$ & $-\mathrm{Cl} 3$ & $3.492(4)$ & -06 & $2.25(2)$ \\
\hline$<\mathrm{Pb} 4-\mathrm{O}>$ & 2.55 & $<\mathrm{Pb} 5-\mathrm{O}>$ & 2.50 & $<\mathrm{Pb} 6-\mathrm{O}>$ & 2.48 & $<$ As2-O $>$ & 1.80 \\
\hline$<\mathrm{Pb} 4-\mathrm{Cl}>$ & 3.25 & $<\mathrm{Pb} 5-\mathrm{Cl}>$ & 3.31 & $<\mathrm{Pb} 6-\mathrm{Cl}>$ & 3.34 & $<\mathrm{Sb} 2-\mathrm{O}>$ & 2.07 \\
\hline
\end{tabular}


ray powder patterns reported by Welin (1968) for ecdemite and heliophyllite do not show any significant difference. In fact, the differences in intensities may well be due to the experimental setup, namely measurement of very absorptive phases in transmission setup with $\mathrm{CuK} \alpha$ radiation. An additional small diffraction peak in the ecdemite pattern at $d=$ $3.05 \AA$ is reported in Welin (1968). This diffraction line cannot be indexed on the basis of the monoclinic cell proposed by Perchiazzi et al. (2019). This is most likely attributable to the presence of admixed finnemanite, contributing with its strongest $(121)$ reflection with $\left(d_{\text {ret }}, I_{\text {rel }}\right)=(3.047,100)$ (Powder Diffraction File 83-1311). The uniaxial minor phase admixed with major biaxial ecdemite reported by Sillén and Melander (1941) is most likely also finnemanite. This hypothesis is in agreement with the presence of a phase very close in chemical composition to finnemanite, admixed within major ecdemite, reported by Jonsson (2003). Finnemanite was also identified as an admixture through XRD data in the present study of holotype heliophyllite. All the diffraction peaks in the heliophyllite X-ray powder pattern (Table 3) can be satisfactorily indexed with the monoclinic pseudo-tetragonal cell proposed in this study. By comparison of data reported in Table 3, it is notable that the dataset (PDF 20-471) presented in Welin (1968) only includes the strongest diffraction lines observed in this study. XRPD data of heliophyllite are in close agreement with those reported by Perchiazzi et al. (2019) for ecdemite, with slight differences due to the quite high absorption of the two phases and to the presence of minor finnemanite and hydrocerussite in the studied heliophyllite sample. We conclude that there is no convincing evidence from literature data of the existence of a $\mathrm{Pb}_{6} \mathrm{As}_{2} \mathrm{O}_{7} \mathrm{Cl}_{4}$ polymorph with tetragonal symmetry, whereas the biaxial optical character reported by Flink (1888), Hamberg (1889), and Sillén and Melander (1941) is in agreement with the monoclinic symmetry found in the single-crystal structure study of ecdemite by Perchiazzi et al. (2019). The Raman spectra of heliophyllite (spectral region of 1200$200 \mathrm{~cm}^{-1}$ ) is reported in Fig. 1, showing bands with overall low intensities, apart from strong bands due to lattice modes $\left(150,124,240 \mathrm{~cm}^{-1}\right)$. Bands due to As-O stretching modes are present at $696\left(v_{1}-\right.$ symmetric mode), 610 and $512 \mathrm{~cm}^{-1}$ ( $v_{3}$ - antisymmetric mode). A band attributable to a $v_{2}$ deformation mode is found at $429 \mathrm{~cm}^{-1}$, and bands at 350,334 and $310 \mathrm{~cm}^{-1}$ are assignable to the $v_{4}$ deformation mode. These data are in excellent agreement with those reported by Jonsson (2003) and by Perchiazzi et al. (2019) for ecdemite.

Atomic positional and displacement parameters for heliophyllite obtained during single-crystal structure refinement are reported in Table 4, with selected bond distances given in Table 5a. For comparison, selected bond distances reported for the ecdemite structure (Perchiazzi et al., 2019) are given in Table 5b. The structural model presented for heliophyllite is identical to that reported for ecdemite by Perchiazzi et al. (2019). The trigonal coordination for the two independent $\mathrm{As}^{3+}$ cations is confirmed, with As-O bond lengths clustered within the narrow $1.80-1.81$ A range. The coordination environment reported for each of the six independent lead atoms is quite comparable to that given by Perchiazzi et al. (2019) for ecdemite. Each independent $\mathrm{Pb}^{2+}$ cation is linked to four $\mathrm{Cl}$ anions, and to three to four oxygen anions, with a resulting VII coordination for $\mathrm{Pb} 1$ and $\mathrm{Pb} 3$ and VIII for the remaining $\mathrm{Pb} 2, \mathrm{~Pb} 4, \mathrm{~Pb} 5$ and $\mathrm{Pb} 6$ independent $\mathrm{Pb}^{2+}$ cations (Table $5 \mathrm{a}$ ). The strongly asymmetric arrangement of anions in the $\mathrm{Pb}$ coordination environment detected in ecdemite is confirmed: oxygen and chlorine are grouped together and located on opposite sides with respect to the central $\mathrm{Pb}^{2+}$ cation (see Fig. 3 in Perchiazzi et al., 2019, for details). As a result of the above considerations, the crystal structure of heliophyllite (Fig. 2) can be described through the occurrence of structural layers, namely litharge-like and $\mathrm{Cl}$ layers, alternating along $c *$ with an 1:1 regular sequence, and the crystal structures of ecdemite and heliophyllite can be considered to be practically identical. In summary, experimental data reported in the present study of heliophyllite do not show any compelling evidence of the existence of heliophyllite as a distinct polymorph of ecdemite.

\section{Conclusions}

Holotype samples of heliophyllite from Harstigen were examined through EPMA, Raman, and XRD single-crystal and powder diffraction methodologies. Raman and XRPD data are in close agreement with ecdemite data reported in recent papers by Jonsson (2003) and Perchiazzi et al. (2019). Heliophyllite is monoclinic, $P 2_{1}$, with $a=10.838(2), b=$ 10.839(2), $c=6.981(1) \AA$ and $\beta=113.28(1)^{\circ}$; with an ideal chemical formula $\mathrm{Pb}_{6} \mathrm{As}_{2} \mathrm{O}_{7} \mathrm{Cl}_{4}$; and with a structural arrangement practically indistinguishable from that of ecdemite. On the basis of the new set of chemical and structural data for the heliophyllite holotype material reported in the present study, the mineral should be considered to be identical to ecdemite. Ecdemite and heliophyllite were defined as new species by Nordenskiöld (1877) and Flink (1888) respectively. As a consequence of historical precedence, ecdemite remains a valid species and heliophyllite should be discredited as a valid mineral species.

Data availability. The single-crystal X-ray diffraction dataset (*.hkl file) can be obtained from the authors upon request. The CIF is deposited in the Supplement.

Supplement. The supplement related to this article is available online at: https://doi.org/10.5194/ejm-32-265-2020-supplement.

Author contributions. NP and UH were responsible for shaping the project. Experimental data were collected by ND (XRPD), NP (Raman, single-crystal XRD) and PV (EPMA). All authors provided 
support in the data interpretation and revised the paper, which was written by NP.

Competing interests. The authors declare that they have no conflict of interest.

Acknowledgements. The authors wish to thank the Commission on New Minerals, Nomenclature and Classification (CNMNC) of the International Mineralogical Association (IMA) for the helpful comments on the proposal of discreditation of heliophyllite. We wish to thank Frantisek Laufek and an anonymous reviewer for their helpful comments and remarks, which significantly improved the paper. Many thanks also to the associate editor, Luca Bindi, and to the chief editor, Sergey Krivovichev. The authors wish to thank Alessandro Pavese, the University of Turin, for providing funds for the EPMA analyses.

Financial support. This research has been supported by the Università di Pisa ("Georisorse e Ambiente" (grant no. PRA_2018_41)), the SYNTHESYS project (grant no. SE-TAF-5983).

Review statement. This paper was edited by Sergey Krivovichev and reviewed by František Laufek and one anonymous referee.

\section{References}

Aurivillius, B.: On the crystal-structure of a number of nonstoichiometric mixed lead-oxide halides composed of PbO like blocks and single halogen layers, Chem. Scripta, 19, 97-107, 1982.

Aurivillius, B.: On the crystal structure of some non-stoichiometric mixed lead oxide halides and their relation to the minerals "lorettoite" and sundiusite, Chem. Scripta, 22, 5-11, 1983.

Boher, P., Garnier, P., Gavarri, J. R., and Hewat, A. W.: Monoxyde quadratique $\mathrm{PbO} \alpha$ (I): Description de la transition structurale ferroélastique, J. Solide State Chem., 57, 343-350, 1985.

Bruker AXS Inc.: APEX 3, in: Bruker Advanced X-ray Solution, Bruker AXS Inc., Madison, WI, USA, 2016.

Chukanov, N. V., Siidra, O. I., Polekhovsky, Y. S., Pekov, I. V., Varlamov, D. A., Ermolaeva, V. N., and Virus, A. A.: Erikjonssonite, $\left(\mathrm{Pb}_{32} \mathrm{O}_{21}\right)\left[(\mathrm{V}, \mathrm{Si}, \mathrm{Mo}, \mathrm{As}) \mathrm{O}_{4}\right]_{4} \mathrm{Cl}_{9}$, a new mineral from the Kombat mine and structural classification of layered lead oxychlorides related to litharge, Eur. J. Mineral., 31, 619-628, https://doi.org/10.1127/ejm/2019/0031-2854, 2019.

Coelho, A. A.: TOPAS and TOPAS-Academic: an optimization program integrating computer algebra and crystallographic objects written in C++, J. Appl. Cristallogr., 51, 210-218, https://doi.org/10.1107/S1600576718000183, 2018.

Farrugia, L. J.: WinGX and ORTEP for Windows: an update, J. Appl. Cristallogr., 45, 849-854, https://doi.org/10.1107/S0021889812029111, 2012.

Flink, G.: Heliophyllit von Pajsberg, Öfvers. Kongl. Vetensk.-Akad. Förh., 45, 574-578, 1888.
Fransolet, A. M.: Etude minéralogique et pétrologique des phosphates de pegmatites granitiques. Unpublished $\mathrm{PhD}$ thesis, University of Liège, 333 pp., 1975.

Hamberg, A.: Optische anomalien des ekdemit (heliophyllit) von Harstigen, Geol. Fören. Stock. För., 11, 229-237, 1889.

Jonsson, E.: Mineralogy and parageneses of $\mathrm{Pb}$ oxychlorides in Långban-type deposits, Bergslagen, Sweden, GFF, 125, 87-98, https://doi.org/10.1080/11035890301252087, 2003.

Krivovichev, S. V., Turner, R., Rumsey, M., Siidra, O. I., and Kirk, C. A.: The crystal structure and chemistry of mereheadite, Mineral. Mag., 73, 103-117, https://doi.org/10.1180/minmag.2009.073.1.103, 2009.

Krivovichev, S. V., Mentre, O., Siidra, O. I., Colmont, M., and Filatov, S. K.: Anion-centered tetrahedra in inorganic compounds, Chem. Rev., 113, 6459-6535, https://doi.org/10.1021/cr3004696, 2013.

Lausi, A., Polentarutti, M., Onesti, S., Plaisier, J. R., Busetto, E., Bais, G., and Pifferi, A.: Status of the crystallography beamlines at Elettra, Eur. Phys. J. Plus, 130, 43, https://doi.org/10.1140/epjp/i2015-15043-3, 2015.

Nordenskiöld A. E.: Nya mineralier från Långban, Geol. Fören. Stock. För., 3, 376-384, 1877.

Palache, C., Berman, H., Frondel, C., and Dana, E. S.: The system of mineralogy of James Dwight Dana and Edward Salisbury Dana, Yale University, 1837-1892: Halides, nitrates, borates, carbonates, sulfates, phosphates, arsenates, tungstates, molybdates, J. Wiley \& Sons, 1951.

Perchiazzi, N., Hålenius, U., Vignola, P., and Demitri, N.: Crystalchemical study of ecdemite from Harstigen, a new natural member of the layered lead oxyhalides group, Eur. J. Mineral., 31, 609-617, https://doi.org/10.1127/ejm/2019/0031-2853, 2019.

Sabine, T. M., Hunter, B. A., Sabine, W. R., and Ball, C. J.: Analytical expressions for the transmission factor and peak shift in absorbing cylindrical specimens, J. Appl. Cristallogr, 31, 47-51, https://doi.org/10.1107/S0021889897006961, 1998.

Sheldrick, G. M.: Crystal structure refinement with SHELXL, Acta Cryst., C71, 3-8, https://doi.org/10.1107/S2053229614024218, 2015.

Siidra, O. I., Krivovichev, S. V., and Filatov, S. K.: Minerals and synthetic $\mathrm{Pb}(\mathrm{II})$ compounds with oxocentered tetrahedra: review and classification, Zeit Krist., 223, 114-125, https://doi.org/10.1524/zkri.2008.0009, 2008.

Siidra, O. I., Krivovichev, S. V., Turner, R. W., and Rumsey, M. S.: Natural and synthetic layered $\mathrm{Pb}(\mathrm{II})$ oxyhalides, in: Minerals as Advanced Materials II, 319-332, Springer, Berlin, Heidelberg, 2011.

Siidra, O. I., Krivovichev, S. V., Turner, R. W., Rumsey, M. S., and Spratt, J.: Crystal chemistry of layered $\mathrm{Pb}$ oxychloride minerals with $\mathrm{PbO}$-related structures: Part I. Crystal structure of hereroite, $\left[\mathrm{Pb}_{32} \mathrm{O}_{20}(\mathrm{O}, \square)\right]\left(\mathrm{AsO}_{4}\right)_{2}\left[(\mathrm{Si}, \mathrm{As}, \mathrm{V}, \mathrm{Mo}) \mathrm{O}_{4}\right]_{2} \mathrm{Cl}_{10}, \mathrm{Am}$. Min., 98, 248-255, https://doi.org/10.2138/am.2013.4241, 2013a.

Siidra, O. I., Krivovichev, S. V., Turner, R. W., Rumsey, M. S., and Spratt, J.: Crystal chemistry of layered $\mathrm{Pb}$ oxychloride minerals with $\mathrm{PbO}$-related structures: Part II. Crystal structure of vladkrivovichevite, $\left[\mathrm{Pb}_{32} \mathrm{O}_{18}\right]\left[\mathrm{Pb}_{4} \mathrm{Mn}_{2} \mathrm{O}\right] \mathrm{Cl}_{14}\left(\mathrm{BO}_{3}\right)_{8} \cdot 2 \mathrm{H}_{2} \mathrm{O}$, Am. Min., 98, 256-261, https://doi.org/10.2138/am.2013.4244, 2013b.

Siidra, O. I., Zinyakhina, D. O., Zadoya, A. I., Krivovichev, S. V., and Turner, R. W.: Synthesis and modular structural architectures 
of mineralogically inspired novel complex $\mathrm{Pb}$ oxyhalides, Inorg. Chem., 52, 12799-12805, https://doi.org/10.1021/ic402066h, 2013c.

Sillén, L. G. and Melander, L.: X-ray studies on the oxihalide minerals nadorite (ochrolite) $\mathrm{PbSbO}_{2} \mathrm{Cl}$ and ekdemite, Zeit Krist., 103, 420-430, 1941.
Welin, E.: Notes on the mineralogy of Sweden. 6. X-ray powder data for minerals from Långban and the related mineral deposits of central Sweden, Ark. Mineral. och Geol., 4, 499-541, 1968.

Wilson, A. J. C.: International Tables for Crystallography, Volume C, Kluwer, 1992. 